\title{
Application of Dare Program for Increased Capabilities of Teenagersin Preventing Drug Abuse Through in Medan
}

\author{
Sri Eka Wahyuni, Wardiyah Daulay, Mahnum Lailan Nst \\ Departement of Psychiatric and Community Nursing, Faculty of Nursing, Universitas Sumatera Utara, \\ Medan, Indonesia
}

\begin{abstract}
Teenagers are a group of humans who are vulnerable to the drug. It is all because of teenagers age have the process of seeking self of identity and focusing on the group's friends. This activity has done in Sari Rejo, Medan Polonia. Medan Polonia is the second area of higher drugs consumption in Medan. DARE Program (Drug Abuse Resistance Education) is one program that has proven effective as an intervention to prevent drug abuse for teenagers. This program is carried out by forming peer educators and then training cognitive, affective and psychomotor peer educator skills to prevent drug abuse. Teenagers can expressly reject the invitation of group friends or their peers to try to consume drugs. The results showed the affective and psychomotor capabilities of teenagers are different pre and post DARE Program ( $\mathrm{p}=0,000$, $\mathrm{p}$-value 0,000). It is recommended that the overall DARE Program is carried out in order to improve the abilities of teenagers to prevent drug abuse.
\end{abstract}

Keywords:Affective, Psychomotor Capability, Teenagers

Abstrak. Remaja adalah kelompok individu yang rentan terhadap narkoba. Hal ini karena masa remaja merupakan masa proses mencari jati diri dan berfokus pada kelompok. Kegiatan pengabdian masyarakat ini dilakukan di Sari Rejo, Medan Polonia. Medan Polonia merupakan daerah rawan peredaran narkoba yang kedua di kota Medan. Program DARE (Drug Abuse Resistance Education) adalah salah satu program intervensi yang efektif intervensi mencegah penyalahgunaan narkoba bagi remaja. Program ini dilakukan dengan membentuk peer group dan kemudian melatih keterampilan peer grup baik kognitif, afektif dan psikomotor untuk mencegah penyalahgunaan narkoba. Remaja dilatih untuk dapat menolak ajakan teman sebaya mereka untuk mencoba mengonsumsi narkoba. Hasil kegiatan menunjukkan kemampuan afektif dan psikomotor remaja berbeda pre dan post Program DARE ( $p=$

\footnotetext{
*Corresponding author at:Jl. Prof. T. Ma'as No. 3 Kampus USU, Padang Bulan, Medan 20155, Indonesia

E-mail address: eka_rizky06@yahoo.co.id
} 
0,000, p-value 0,000). Program DARE direkomendasikan dilakukan untuk meningkatkan kemampuan remaja untuk mencegah penyalahgunaan narkoba.

Kata Kunci: Afektif, Kemampuan Psikomotor, Remaja

Received17 November 2018 | Revised 2 April 2019| Accepted 4 April 2019

\section{Introduction}

Narcotics, psychotropic and addictive substances (NAPZA) are a problem that is very concerning in Indonesia. The rise of drug abuse is not only in big cities, but also has reached small towns and has even reached all socio-economic strata of the community and the victims are not only adults but also children and adolescents. Currently, drugs are widely consumed by children and adolescents aged 15-24 years. Imagine how heavy the burden must be borne by victims, families and all Indonesians due to drug abuse.

Indonesia has become trafficking in illegal drugs and not only as a transit and marketing area, but Indonesia has also become a drug producer. This is evidenced by the disclosure of drug manufacturing plants and a large number of imported drug makers in Indonesia. This is also strengthened by Indonesia's strategic location because it is not far from the golden triangle area (Laos, Thailand, and Myanmar) and the Crescent region (Iran, Afghanistan and Pakistan) which are the largest opium-producing regions in the world [5].

Drug use cases are increasingly increasing; Marijuana-type drug abusers in the world reach 162.4 million people [9]. For the type of stimulant amphetamine (ATS) as many as 35 million people. And of that number, users of methamphetamine reached 25 million and ecstasy of 10 million. Meanwhile cocaine users are 13.4 million people.

The National Narcotics Agency (BNN) estimates that there are around 1.5 percent of the total populations of Indonesia or around 3.2 million people who have become drug victims. Of these, there are 800,000 syringe drug users and 60 percent of these have been infected with HIV/AIDS. The National Narcotics Agency also estimates that every year there are 15,000 Indonesians who die from an overdose and are also infected with HIV/AIDS. If the amount is averaged per day, every day there are 40 Indonesian people dying from drugs [9]. Drug use cannot only cause death due to overdose and HIV/AIDS but also adversely affect the health status of individuals because it causes physical changes, attitudes and behavior of individuals become maladaptive. 
The burden on the world community is $8.9 \%$ due to drug dependence [16]. Socio-economic costs due to the use of drugs in Indonesia amounting to 32.3 trillion rupiah per year (including all components including maintenance and correction costs) [18]. The 2011 study updated the number of socio-economic losses in Indonesia in a year due to the use of addictive substances to be 44 trillion rupiah with an estimated prevalence of $2.2 \%$ [18]. But given the course of the disease, it appears that addiction will persist for many years, and will multiply the possible effects of the danger of drug abuse [10].

Adolescent age is an age that is vulnerable to drug abuse due to negative interactions with peers. At this time also drug cases have penetrated into students. $22 \%$ of drug cases are teenagers. This phenomenon can be prevented from occurring in adolescents [13]. For this reason, an effort or program is needed to prevent drug abuse by involving the role of community groups in Sari Rejo, Medan Polonia.

\section{Method}

The DARE program for adolescents in Sari Rejo Village is by modifying previous research through the following stages: detection of adolescents who meet the criteria to be the formation of Peer Educators, adolescent Cognitive, Affective and Psychomotor pre-test before the DARE Program, DARE Program implementation is by training Peer Educators on Mental Health and Adolescent Development, how to manage stress, drug and Its impact on the body, and how to increase adolescent confidence [13]. The process of the DARE Program can be seen in the picture below:

1. Teenagers Selection to be a Peer Group

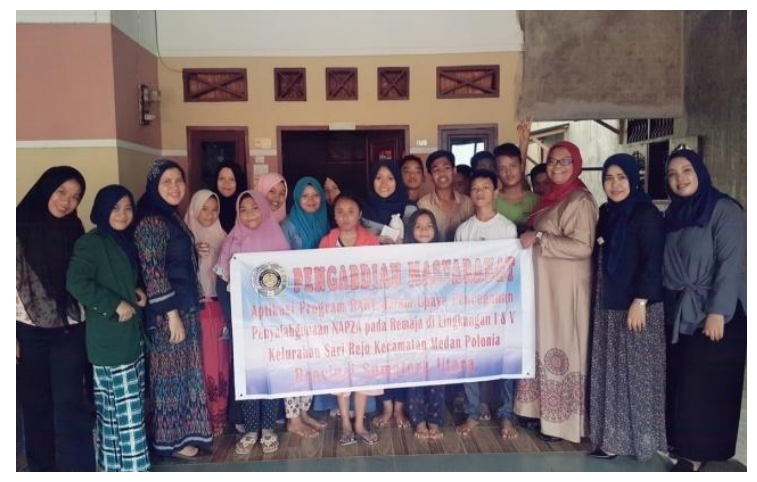

Figure 1.Teenagers Selection 
2. Pre Test Affective and Psychomotor Capabilities

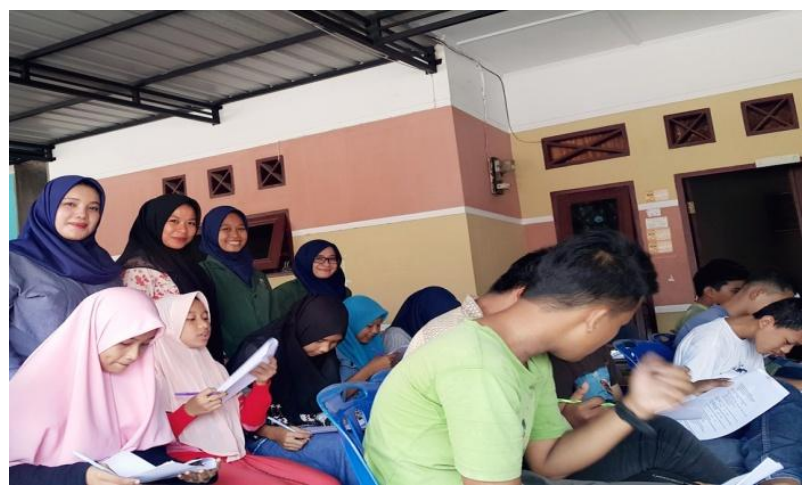

Figure 2.Pre Test

3. Training Peer Educators on Mental Health and Adolescent Development, how to manage stress, drug and Its impact on the body, and how to increase adolescent confidence.
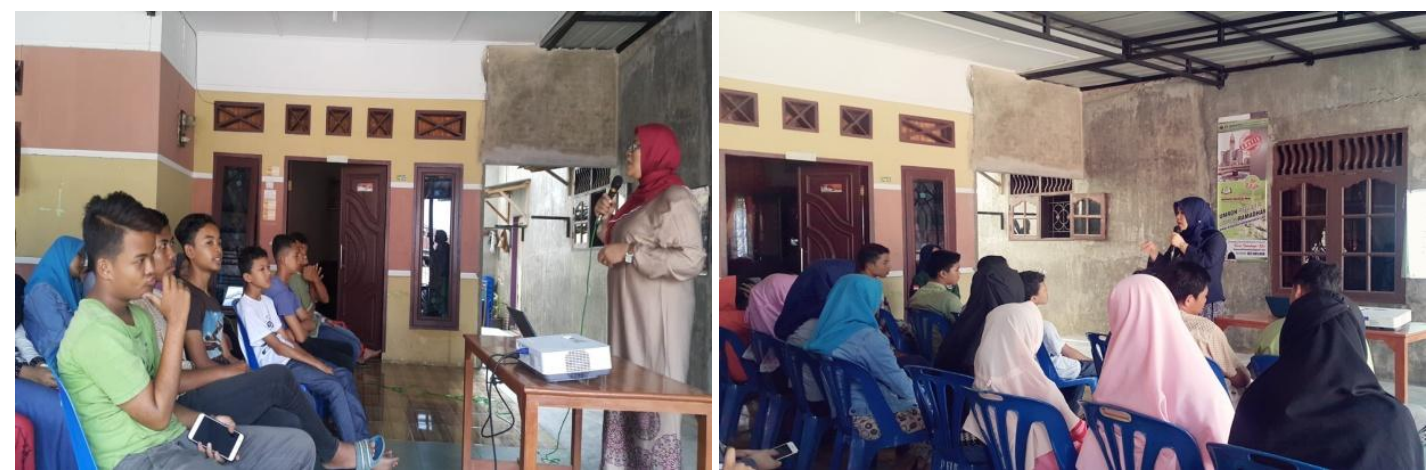

Figure 3.Training in DARE Program

\section{Result and Discussion}

The results showed that the majority of adolescents were men 19 people $(63.3 \%)$, their education was junior high school 17 people (56.7\%), a house with parents 29 people (96.7\%). Characteristics of adolescents in the DARE Program can be seen in table 1 below:

Table 2 showed Affective and Psychomotor Capabilities of Teenagerspre andpost DARE Program. The result showed affective and psychomotor capabilities of teenagers are different pre and post DARE Program ( $\mathrm{p}=0,000$, $\mathrm{p}$-value 0,000).

The results showed Affective and Psychomotor Capabilities of Teenagerspre andpost DARE Program. The result showed affective and psychomotor capabilities of teenegers are different pre and post DARE Program ( $\mathrm{p}=0,000$, $\mathrm{p}$-value 0,000$)$. 
Table 1. Characteristics of Respondents

\begin{tabular}{lcc}
\hline \multicolumn{1}{c}{ Characteristics } & Frequency & Persentage (\%) \\
\hline Gender & 11 & 36.7 \\
a. Female & 19 & 63.3 \\
b. Male & & \\
Education & 17 & 56.7 \\
a. Junior High School & 9 & 30.0 \\
b. Senior High School & 4 & 13.3 \\
c. College Participants & & \\
Living with & 29 & 96.7 \\
a. Parents & 1 & 3.3 \\
b. Other Family & 23 & 76.7 \\
Pocket Money & 6 & 20.0 \\
a. <10 thousand rupiah & 1 & 3.3 \\
b. 10-50 thousand rupiah & & \\
c. > 50 thousand rupiah & 4 & 13.3 \\
Extracurricular Program & 8 & 26.7 \\
a. Scout Organization & 14 & 46.7 \\
b. Sports & 4 & 13.3 \\
c. Youth of Mosque & & \\
d. Others & 3 & 10.0 \\
Ethnics & 5 & 73.3 \\
a. Malay & 22 & \\
b. Batak & & \\
c. Javanese & & \\
\hline
\end{tabular}

Table 2. Affective and Psychomotor Capabilities of Teenagers Pre and Post DARE Program

\begin{tabular}{ccccccc}
\hline Characteristics & N & Mean & SD & SE & T & p-value \\
\hline Affective & & & & & & \\
a. Pre & 30 & 136.00 & 15,667 & 2,860 & 50,104 & 0,000 \\
b. Post & 30 & 556,27 & 61,546 & 11,237 & & \\
\hline Psychomotor & & & & & & \\
a. Pre & 30 & 281,20 & 32,443 & 5,923 & 54,362 & 0,000 \\
b. Post & 30 & 1143,83 & 106,933 & 19,523 & & \\
\hline
\end{tabular}

Knowledge is the result of knowing and occurs after people sensing certain objects [17]. Knowledge is a very important domain in shaping one's actions. So it can be concluded that before the individual takes action, the individual must know in advance the benefits of the action for himself through the process of giving information or increasing knowledge. This statement was reinforced by WHO [17] which states that strategies to change individual behavior are grouped into 3 namely using power, providing information and discussion of participation. And giving information will increase 
individual knowledge. Furthermore, the knowledge gained through information will generate awareness and finally, the individual will behave according to the knowledge he has. The results of changes in behavior will be lasting because they are based on individual awareness and not due to coercion.

The exercise itself is an important thing in the learning process. Training is the improvement of the potential of existing forces by repeating certain activities; training is the main activity in the learning process, as well as habituation or culture. Exercise and refraction occur in the biological level, but if it later develops towards psychic, there will be a process of automatism [17]. The process produces unconscious, fast and precise actions. The above statement is also reinforced by Bandura [17] which states that in observational learning, there are 4 important elements which include: paying attention, storing information, producing behavior and being motivated in repeating the behavior. And in the process of producing behavior, individuals need a lot of practice, feedback because it will make the behavior more proficient.

The DARE program (Drug Abuse Resistance Education) has been around since 1983 in Los Angeles. The DARE program is a preventive effort that focuses on students to improve their ability to resist or resist peer pressure to consume drugs. This program is used in 54 countries including the United States and Canada [4]. The DARE program prevents the use of drugs in school-age children and helps them develops effective groups and refuses abuse by refusing techniques or techniques [3].

This DARE program has proven to be effective in preventing drug abuse DARE Program is recommended to be conducted in schools as an effort to prevent drug use in students in Depok [13]. The DARE program can increase self-esteem, improve children's knowledge and skills in preventing drug use, improve assertive behavior, improve problem-solving and make decisions. Besides DARE can also improve communication skills and prevent violence [3].

The research mentioned that knowledge of the teenagers who followed DARE program are having a significant relation towards the risk of teenagers who smoke. Teenagers' knowledge also has a strong relation to the behavior of teenagers who smoked [1]. This program also gives positive impact to prevent smoking behavior. DARE program gave a positive impact by increasing the awareness, perception of teenagers behavior in understanding the negative impact of NAPZA [11]. Besides the increase in knowledge, 
psychomotor, and teenagersbehavior towards NAPZA, DARE program also increases the awareness of parents on the impact of NAPZA and its danger [6].

On the other hand, research mentioned that the DARE program was not effective enough to increase the knowledge, psychomotor, and teenagers behavior to prevent the misuse of NAPZA [15]. The result of Perry's research also mentioned that there is no behavior difference with the respondents who followed the DARE program and the respondents who didn't follow the program. There was no effect with the psychosocial behaviour in NAPZA prevention program [7]. It happened due to the lack of time to implement the DARE program. The estimation of the research is mostly done in one semester or around 6 months. That was the reason why the result of the program is not appropriate with the targeted purpose.

\section{Conclusion}

Based on this research, the researcher recommends doing DARE Program in the school community to increase the ability of psychomotor, and teenager's affective as the efforts to prevent the misuse of NAPZA.

\section{Acknowledgments}

We would like to show our gratitude to Universitas Sumatera Utara that has funded the community service program.

\section{References}

[1] Nasar Ahmed, Noushin Ahmed, Ray Bennet and Joseph Hinds (2014). Impact of a Drug Abuse Resistance Education(D.A.R.E) program in preventing the initiation of cigarette smoking in fifth- and sixth-grade students. Journal of National Education. April 2002.

[2] Analisa Daily (2016). Sumut Peringkat Peringkat Tiga Penggunaan Narkoba. Harian Analisa. 19 January 2016.

[3] BJA (1995). Drug Abuse Resistance Education (DARE). Department of Justice Office United States. September 1995.

[4] Cohen \& Watkinson (2005) A Review of the Research on the Drug Abuse Resistance Education (D.A.R.E.) Program. School of Criminology and Criminal Justice University College of the Fraser Valley. November 2005.

[5] Wahyudi Aulia Siregar(2018).40 Orang di Indonesia Meninggal Setiap Harinya Karena NAPZA. Oke News. 12 Mei 2018. 
[6] Lucas Wayne (2008). Parents' Perceptions of the Drug Abuse Resistance Education Program (DARE). Journal of Child and Adolescent Substance Abuse. Volume 17, 2008.

[7] Wei Pan and Haiyan Bai (2009). A Multivariate Approach to a Meta-Analytic Review of The effectiveness of the D.A.R.E. Program. International Journal of Environmental Research and Public Health.January 2009.

[8] Perry, Komro, Mortenson, Farbachk, Munson, Stigler, and Lytle (2003). A Randomized Controlled Trial of Middle and Junior High School DARE and DARE plus Program. NCBI Pubmed. Februari 2003.

[9] Persda Network (2008). Pengguna NAPZA di Indonesia. Kompas 19 Juni 2008.

[10] Prasetyo \& Utami (2014). Prevalensi Sekunder Penggunaan NAPZA. Buletin Jendela Data dan Informasi. Depkes RI. Semester I, 2014.ISSN.2088-270X.

[11] Ringwalt, C., Ennett, S. T., \& Holt, K. D. (1991). An outcome evaluation of project DARE (drug abuse resistance education). Health education research, 6(3), 327-337. https://doi.org/10.1093/her/6.3.327

[12] Santama (2016). BNN Sumut Grebek Rumah di Medan, Ciduk 2 orang dan $20 \mathrm{Kg}$ ganja.Detik News. 16 Maret 2016.

[13] Suprayatna (2014). DARE is a strategy for nursing intervention community to prevent the drug abuse of NAPZA. Karya Tulis Ilmiah Universitas Indonesia.

[14] Suprayatna (2016). DARE is a strategy for nursing intervention community, Misuse of NAPZA in SMK Cimanggis Depok. Jurnal Kesehatan Medika Saintika. Volume 7.No. 1 Juni 2016.

[15] West and O’Neil (2004). Project D.A.R.E. Outcome Effectiveness Revisited. American Journal of Public Health.Juni 2004.

[16] WHO (2004). Global Status Report on Alcohol 2004. World Health Organization Department of Mental Health and Substance Abuse Geneva 2004.

[17] Notoatmodjo (2007). Promosi Kesehatan dan Ilmu Perilaku. Penerbit Rineka Cipta, Jakarta.

[18] BNN (2018). BNN Ingatkan 50 Orang Meninggal Setiap Hari karena Narkoba. Kementrian Komunikasi dan Informatika Republik Indonesia. 